\title{
EVALUATION OF EVAPORATIVE COOLING SYSTEMS IN INDUSTRIAL BUILDINGS
}

\author{
Alessandra De Angelis*, Marco Medici ${ }^{\circ}$, Onorio Saro* and Giulio Lorenzini ${ }^{\circ}$ \\ * Department of Electrical Management and Mechanical Engineering, University of Udine, Via Delle Scienze, \\ 206, 33100 Udine, Italy; \\ ${ }^{\circ}$ Department of Industrial Engineering, University of Parma, Parco Area delle Scienze 181/A, 43124 Parma, \\ Italy.
}

Email: marco.medici@unipr.it

\begin{abstract}
The cooling energy requirements are certainly a key issue in warm climates. Vapour compression refrigeration systems involve high energy consumptions and environmental emissions and that makes this kind of technology unattractive. These aspects are most relevant in buildings which have high volume and high internal thermal loads as happens often in industrial buildings. For this kind of buildings a sustainable alternative to improve indoor thermal conditions is represented by evaporative cooling systems. Such systems take advantage of the water evaporation process to cool an air stream, which could cool the supplied air or which could be itself the supplied air to the conditioned environment.

In this paper a wide analysis of evaporative cooling applications is presented referring to a sample industrial building characterized by relevant thermal discomfort. The thermal behaviour of building has been evaluated using the transient simulation program TRNSYS, in which different study cases are implemented on varying the cooling system. Moreover, a kind of indirect evaporative cooling systems, called cyclic evaporative cooling, in which the air temperature can be reduced below the wet bulb temperature, has been designed. The results of the simulations were compared in terms of energy savings and thermal comfort.
\end{abstract}

Keywords: Direct and indirect evaporative cooling, Air conditioning, Thermal comfort, Industrial building, Saving energy.

\section{INTRODUCTION}

In last decades the achievement of internal comfort conditions became an important target in many fields. Almost all residential buildings in warm and humid climates are equipped with a cooling system, as well the hotels, which work during the summer period. Also the most cars are equipped with an air conditioning system.

Industrial buildings are places where often there are not acceptable comfort conditions, because of processing needs or high installation and operation costs of cooling and heating plants. The more critical conditions occur during the summer period, when thermal loads due to machinery affect the internal air temperature and climate conditions do not allow to mitigate its consequent increase, whereas during winter period heat losses contribute to mitigate the indoor temperature.

The improvement of thermal conditions in industrial buildings is not only a sign of respect for workers, but also a way for increasing their productivity, as demonstrated in various studies. Temperature level and productivity rate were observed in a Malaysian automotive industry and data were elaborated using Artificial Neural Network analysis; in this study it appears that the optimum value of productivity correspond to a wet bulb globe temperature value (WBGT) of $24.5^{\circ} \mathrm{C}$ [1]. In a previous study on the same industrial site, the authors evaluated a PPD index around to $80 \%$ while the PMV index showed that the area of work is slightly warm [2]. Sherif and Mohamed proposed a PMV-productivity model that verifies a relationship among productivity, climatic, activity, and personal parameters; such model was validated with data collected from four construction sites in North East of Thailand over a period of 14 weeks during the cool and dry season [3, 4]. Zhao et al. carried out human body experiments and statistics analysis of their results in order to establish a heat tolerance time model and a productivity model. Experimental data are obtained in three conditions of physical labour intensity inside a chamber stimulating a hot and humid environment [5].

Often, the reason why no intervention are made is the high installation and operation costs of a HVAC system based on compression vapor equipments. The aim of this work is to identify a plant which could mitigate the internal air temperature in industrial buildings and which at the same time requires less cooling energy than a conventional vapour compression cooling system. In order to reach this intent in this work both direct and indirect evaporative cooling systems are analysed and implemented.

In a direct evaporative cooling system hot external air flows through a porous wetted medium (evaporative pad) or through a fine water spray. The water absorbs heat from air flow stream and evaporates, reducing the air temperature. In 
fact, this is an adiabatic saturation process in which the air dry bulb temperature is reduced as its humidity increases. The minimum temperature that the air can reach is the wet bulb temperature $t_{w b}$ of the entering air [6-9].

System wetting effectiveness is the decrease of the air dry-bulb temperature divided by the difference between the dry and wet-bulb temperatures of the air. The process is $100 \%$ effective when the air is cooled to the wet-bulb temperature. The effectiveness of direct evaporative cooling systems, in terms of temperature reduction, is approximately $70-95 \%[10,11]$. The cooling effect is as high as the moisture content of the external air is low, therefore the evaporative cooling system is very suitable for hot and temperate climates, where the humidity is usually low also in the hot season $[12,13]$. In hot and humid climates an indirect evaporative cooling systems are more efficient in terms of igrothermal comfort since they do not allow for increasing the moisture content of the supplied air. In a simple indirect evaporative cooling system the external air flows through the channels of a heat exchanger and its temperature is reduced by a secondary air stream, which is cooled by a direct evaporative system. In this way, it a sensible cooling of the supplied air is normally observed, without change in its moisture content and for this reason it is more attractive than a direct evaporative system. However, the cooling effectiveness is generally low, around 40-60\% $[14,15]$ and the installation cost is higher.

\section{INDUSTRIAL BUILDING MODEL}

\subsection{Geometry and materials}

The current study has been carried out on an existing industrial building located in the North of Italy (46 3 'latitude, $13^{\circ} 14$ 'longitude and $113 \mathrm{~m}$ altitude), where during the summer period the climate is hot and humid. The industrial shed is a single floor building with a total gross area of $4800 \mathrm{~m}^{2}$ and $7 \mathrm{~m}$ high. Figure 1 shows a rendering of the sample building. The total windowed surface, the total external doors area and the external wall surface are $576 \mathrm{~m}^{2}$, $1396 \mathrm{~m}^{2}$ and $240 \mathrm{~m}^{2}$, respectively; the thermo-physical properties of the building materials are reported in Table 1.

\subsection{Simulation parameters}

The building energy analysis has been carried out using the transient simulation program TRNSYS, which can be used to assess the performance of thermal and electrical energy systems. The program models each component in the system as a module, allowing access to the source code for appropriate adaptation. Firstly, the graphical interface TRNBuild, a tool integrated to TRNSYS, has been used in order to define the thermal and geometric characteristics of the building envelope and to model the single-zone building, then the behavior of building was modeled with TRNSYS type 56. The weather data, needed for simulations, are read by means of TRNSYS type 109. The humidification and cooling processes of air are modeled with a psychrometrics utility subroutine (TRNSYS Type 33), whereas the air to air heat exchanger is modeled with TRNSYS type 91, which simulates the behavior of a constant effectiveness device.

For the simulations (time step $0.5 \mathrm{~h}$ ), the period between $15^{\text {st }}$ May and $30^{\text {th }}$ September was considered. The following time scheduling for the workers was assumed: 24 hours a day, starting from Monday at 2:00 to Saturday at 2:00 h.

The internal sensible heat gain of a building consists of the occupants, solar radiation, electric lights, equipments and appliances. Among them, the thermal load due to production machines is the most relevant component of building thermal balance and it is the main reason of thermal discomfort. For this reason only the sensible heat gain due to the machine load $\mathrm{Qmach}_{\text {mas }}$ been taken in to account and it was expressed as [16]:

$$
\mathrm{Q}_{\text {mach }}=2546 \mathrm{P}_{\text {hp }} \mathrm{F}_{\text {load }} \mathrm{F}_{\text {use }}\left(1-\mathrm{F}_{\text {exh }}\right) / \eta_{\text {mo }}
$$

Where $\mathrm{P}_{\mathrm{hp}}$ is the rated horsepower of machine, $\mathrm{F}_{\text {load }}$ is the load factor indicating ratio of actual power required to rated power, $F_{u s e}$ is a use factor indicating the actual used equipment and appliance to the total installed-ratio, $F_{\text {exh }}$ is the heat removal factor due to mechanical exhaust system, and $\eta_{\text {mo }}$ is the motor efficiency.

Setting the value of internal gains of equipments, $80 \%$ of the thermal load has been established as convective heat while the remaining $20 \%$ has been considered radiant heat.

The infiltration air flow rate was assumed to be a sum of a variable part and a fixed part, set equal to 0.2 air changes per hour $(\mathrm{ACH})$, which is a suitable value for a not airconditioned building during the summer period.

The variable part of infiltration air flow models the presence of a servo-motor connected to a control unit, which controls the opening of the windows when the external air temperature is lower of 2 degrees than internal air temperature. The windows opening and closing system works during all week. The variable air flow rate is equal to $0,6 \mathrm{ACH}$ and its temperature is the one of external air.

In order to allow a correct numerical simulation for TRNSYS the following logical conditions, governing the opening and closing of windows, have been defined:

$$
\mathrm{T}_{\text {a.int. }}>\mathrm{T}_{\text {a.ext. }} \text { and } \mathrm{T}_{\text {a.ext. }}>14^{\circ} \mathrm{C}
$$

In which $\mathrm{T}_{\mathrm{a} . \mathrm{int}}$ is the internal air temperature and $\mathrm{T}_{\mathrm{a} . \mathrm{ext}}$ is the external air temperature. These conditions are satisfied when the internal environment is particularly warm $\left(\mathrm{T}_{\mathrm{a} . \text { int. }}>\mathrm{T}_{\mathrm{a} . \mathrm{ext}}\right)$ and only during the summer period $\left(\mathrm{T}_{\text {a.ext. }}>14^{\circ} \mathrm{C}\right)$, since during winter period heat losses contribute to mitigate the indoor temperature.

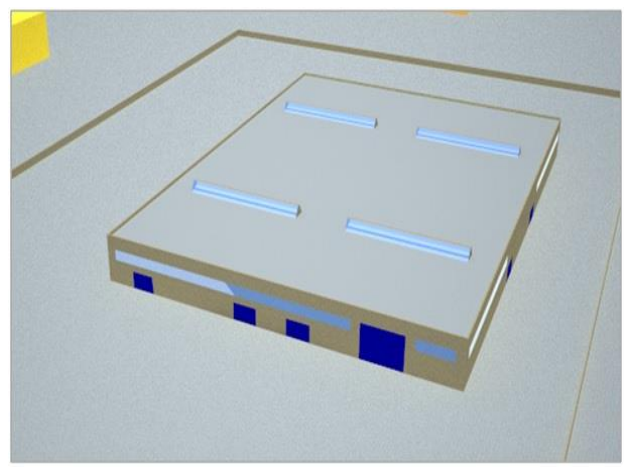

Figure 1. Sample building

The thermal behaviour for the internal environment was modelled and simulated considering weather conditions corresponding to a reference year. 


\section{CASE STUDIES}

The results obtained with different cooling systems have been compared in terms of internal comfort and energy saving. In particular, seven cases have been taken into account and their features are summarized in Table 2. Note that for each option analysed the mass air flow due to infiltration was considered as additional contribution, even it was not cited in explicit form in the following case studies. Also, the devices taken into account in each case study were considered starting 2 hours before the weekly time planning, i.e. from Monday to Friday from 0:00 to 24:00 h, and Saturday from 0:00 to 2:00 h. All assumed settings and operating conditions are given in Table 2 .

\subsection{Ventilation with external air (cases A, B and C)}

While the case $\mathrm{A}$ is not provided with any mechanical system, cases $\mathrm{B}$ and $\mathrm{C}$ are characterized by mechanical ventilation based only on external air. In both cases there are 4 axial-flow fans operating during the working time. In case $\mathrm{B}$, two fans (1.1 kW each) supply a constant air flow rate equal to $0.5 \mathrm{ACH}$ and the additional two fans $(7.5 \mathrm{~kW}$ each), operate when the indoor temperature is greater than $25^{\circ} \mathrm{C}$ and modulating supply up to $3.5 \mathrm{ACH}$ (Table 3 ).

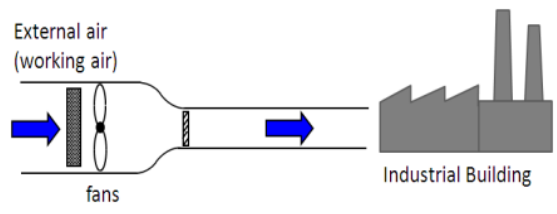

Figure 2. Sketch of ventilation plant in cases B and C

In case $\mathrm{C}$, two additional $11 \mathrm{~kW}$ fans supply an air flow rate equal to $3,5 \mathrm{ACH}$ when the internal air temperature reach $25^{\circ} \mathrm{C}$ and an air flow rate equal to $5 \mathrm{ACH}$ when the internal air temperature reach $28^{\circ} \mathrm{C}$ (Table 3 ).

Figure 3 shows the internal air temperature estimated without any ventilation system (Case A), with the ventilation system of case $B$ and the external air temperature from weather data; in order to distinguish more clearly the temperature profiles is represented the third week of July, which usually is the warmest week in the year. As one can note, during the working time, the internal air temperature is above the external one, mainly because of the relevant internal thermal loads. The internal temperature profiles obtained in cases B and C are very similar, therefore in figure only either has been reported.

\subsection{Ventilation with direct evaporative cooling (Case D)}

The same system of case B is here considered, with the addition of a direct evaporative cooling system (DEC). The DEC consists of an adiabatic wetting equipment used to lower the temperature of the external ventilation air (Figure 4(a)). The adiabatic system is supposed to have a wetting efficiency of $90 \%$. The ventilation air flow passes through the DEC apparatus only if the internal air temperature is higher than $25^{\circ} \mathrm{C}$ and the external air temperature is higher than $19^{\circ} \mathrm{C}$.
Table 1. Details of building construction materials

\begin{tabular}{|l|l|l|l|l|}
\hline & $\begin{array}{l}\text { Thermal } \\
\text { transmittanc } \\
\mathrm{e}\left(\mathrm{W} / \mathrm{m}^{2} \mathrm{~K}\right)\end{array}$ & $\begin{array}{l}\text { Thickness } \\
(\mathrm{m})\end{array}$ & $\begin{array}{l}\text { Thermal } \\
\text { conduc- } \\
\text { tivity } \\
(\mathrm{W} / \mathrm{m} \\
\mathrm{K})\end{array}$ & $\begin{array}{l}\text { Thermal } \\
\text { resistance } \\
\left(\mathrm{m}^{2} \mathrm{~K} /\right. \\
\mathrm{W})\end{array}$ \\
\hline $\begin{array}{l}\text { External } \\
\text { walls }\end{array}$ & 0.362 & & 1.08 & 0.046 \\
\hline Concrete & & 0.05 & 0.04 & 2.5 \\
\hline Polystyrene & & 0.1 & 1.08 & 0.046 \\
\hline Concrete & & 0.05 & & \\
\hline $\begin{array}{l}\text { External } \\
\text { doors }\end{array}$ & 0.461 & & 44.44 & 0.00007 \\
\hline Steel & & 0.003 & 0.04 & 2.0 \\
\hline Polystyrene & & 0.08 & 44.44 & 0.00007 \\
\hline Steel & & 0.003 & & \\
\hline Roof & 0.666 & & 1.08 & 0.046 \\
\hline Concrete & & 0.05 & 0.04 & 1.25 \\
\hline Polystyrene & & 0.05 & 1.08 & 0.065 \\
\hline Concrete & & 0.07 & & \\
\hline Floor & 1.749 & & 1.08 & 0.278 \\
\hline Concrete & & 0.3 & 2.42 & 0.124 \\
\hline $\begin{array}{l}\text { Rock and } \\
\text { clay }\end{array}$ & & 0.3 & & 0.05 \\
\hline Windows & 5.68 & 0,05 & 1 & \\
\hline $\begin{array}{l}\text { Single } \\
\text { layer glass }\end{array}$ & & & & \\
\hline $\begin{array}{l}\text { Metal } \\
\text { frame }\end{array}$ & & & & 0.169 \\
\hline
\end{tabular}

The operating conditions and corresponding air flow rates for the different cases are reported in Table 2, whereas fans motor power are given in Table 3 .

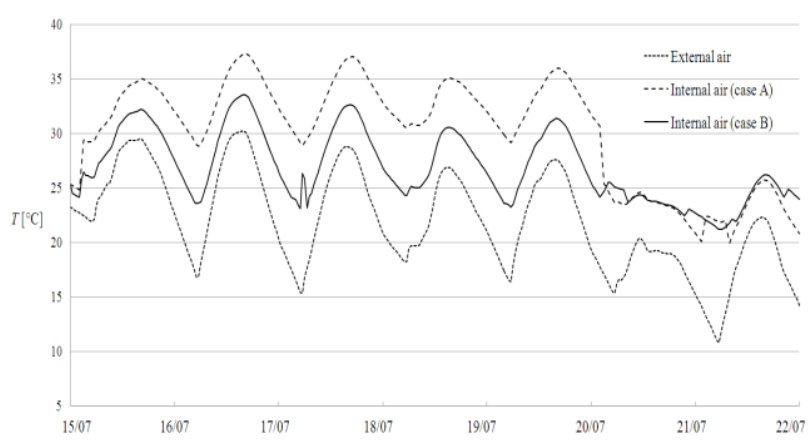

Figure 3. Hourly temperature profiles of internal air without any ventilation system (case A), with ventilation system of case B and external air during the third week of July.

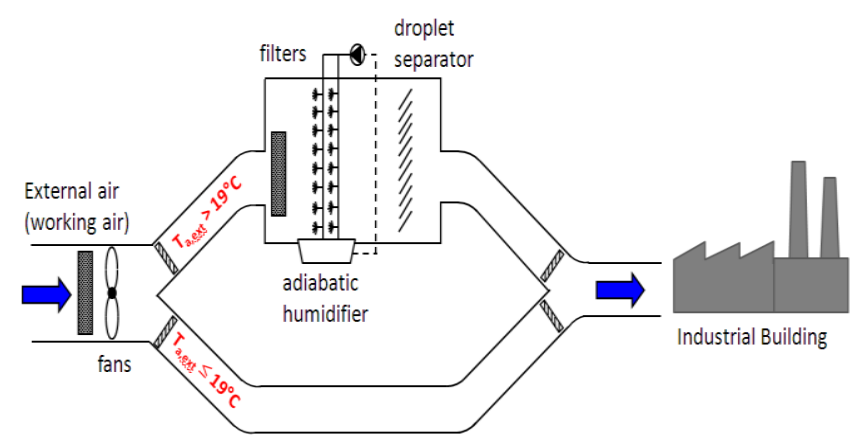

Figure 4(a). Sketch of ventilation plant in case D 


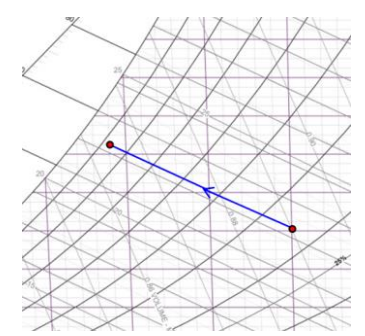

Figure 4(b). Transformation process of external air in case $\mathrm{D}$ on the psychrometric chart

In Figure 5 a comparison between the results of cases $\mathrm{C}$ and $\mathrm{D}$, in terms of internal air temperature, is reported. It can be noted that the direct evaporative system allows to maintain the internal air temperature under the values obtained when there is only a ventilation system with external air (cases B and C).

3.3 Ventilation with indirect evaporative cooling (cases $\mathrm{E}$, F and G)
In this cases the building is equipped with an indirect evaporative cooling system (IEC) instead of a DEC. An external air flow, treated by the evaporative cooler, is used to cool the ventilation air flow by means of an air-air heat exchanger. The evaporative cooler is driven by two fans ( 7.5 $\mathrm{kW}$ each) as in the cases B, C and D. After passing through filters, external air is saturated within the direct evaporative cooler whose wetting efficiency is supposed to reach $90 \%$; then, thanks to the high pressure provided by the additional fan, the working air flows into an air-to-air heat exchanger characterized by $85 \%$ thermal efficiency, which cools the external air without modifying its moisture content. In this way the latter flow (product air) is subjected to a sensible cooling. A sketch of this system is represented in Figure 6(a), and processes of product and working air are illustrated on a psychrometric chart in Figure 6(b).

Three IES-systems, each one characterized by a different flow rate, has been considered. The conditions under which the IEC system operate and relative air flow rates are reported in Table 2, whereas fans motor power are given in Table 3.

Table 2. General settings and conditions for the case studies considered

\begin{tabular}{|c|c|c|c|c|c|c|}
\hline & \multicolumn{2}{|c|}{ Infiltration } & \multicolumn{2}{|c|}{ Ventilation } & \multicolumn{2}{|c|}{ Evaporative system } \\
\hline & $\begin{array}{l}\text { air flow } \\
\text { rate } \\
\text { (vol/h) }\end{array}$ & $\begin{array}{l}\text { Period and } \\
\text { conditions }\end{array}$ & $\begin{array}{l}\text { air flow } \\
\text { rate } \\
\text { (vol/h) }\end{array}$ & $\begin{array}{l}\text { Period and } \\
\text { conditions }\end{array}$ & $\begin{array}{l}\text { air flow } \\
\text { rate } \\
\text { (vol/h) }\end{array}$ & $\begin{array}{l}\text { Period and } \\
\text { conditions }\end{array}$ \\
\hline \multirow{2}{*}{$\begin{array}{l}\text { Absence of } \\
\text { ventilation } \\
\text { system (A) }\end{array}$} & 0.2 & always & & & & \\
\hline & 2 & & & & & \\
\hline \multirow{2}{*}{$\begin{array}{l}\text { Ventilation } \\
\text { with external } \\
\text { air (B) }\end{array}$} & 0.2 & Stoptime & 0.5 & always & & \\
\hline & 0.6 & Worktime * & 3.5 & $\begin{array}{l}\text { Worktime } \\
* *\end{array}$ & & \\
\hline \multirow{2}{*}{$\begin{array}{l}\text { Ventilation } \\
\text { with external } \\
\text { air }(\mathrm{C})\end{array}$} & 0.2 & Stoptime & 0.5 & always & & \\
\hline & 0.6 & Worktime * & 5 & $\begin{array}{l}\text { Worktime } \\
* *\end{array}$ & & \\
\hline \multirow{2}{*}{$\begin{array}{l}\text { Direct } \\
\text { evaporative } \\
\text { cooling (D) }\end{array}$} & 0.2 & Stoptime & 0.5 & always & 3.5 & $\begin{array}{l}\text { Worktime } \\
* * * *\end{array}$ \\
\hline & 0.6 & Worktime $*$ & 3.5 & $\begin{array}{l}\text { Worktime } \\
* * *\end{array}$ & & \\
\hline \multirow{2}{*}{$\begin{array}{l}\text { Indirect } \\
\text { evaporative } \\
\text { cooling (E) }\end{array}$} & 0.2 & Stoptime & 0.5 & always & 3.5 & $\begin{array}{l}\text { Worktime } \\
* * * * *\end{array}$ \\
\hline & 0.6 & Worktime * & 3.5 & $\begin{array}{l}\text { Worktime } \\
* * *\end{array}$ & & \\
\hline \multirow{2}{*}{$\begin{array}{l}\text { Indirect } \\
\text { evaporative } \\
\text { cooling }(F)\end{array}$} & 0.2 & Stoptime & 0.5 & always & 3.5 & $\begin{array}{l}\text { Worktime } \\
* * * * *\end{array}$ \\
\hline & 0.6 & Worktime * & 3.5 & $\begin{array}{l}\text { Worktime } \\
* * *\end{array}$ & 1.5 & $\begin{array}{l}\text { Worktime } \\
* * * * *\end{array}$ \\
\hline \multirow{2}{*}{$\begin{array}{l}\text { Indirect } \\
\text { evaporative } \\
\text { cooling }(G)\end{array}$} & 0.2 & Stoptime & 0.5 & always & 1.5 & $\begin{array}{l}\text { Worktime } \\
* * * * *\end{array}$ \\
\hline & 0.6 & Worktime * & 1.5 & $\begin{array}{l}\text { Worktime } \\
* * *\end{array}$ & 3 & $\begin{array}{l}\text { Worktime } \\
* * * * *\end{array}$ \\
\hline \multirow{2}{*}{$\begin{array}{l}\text { Cyclic } \\
\text { evaporative } \\
\text { cooling }(\mathrm{H})\end{array}$} & 0.2 & Stoptime & 0.5 & always & 3.5 & $\begin{array}{l}\text { Worktime } \\
* * * * *\end{array}$ \\
\hline & 0.6 & Worktime * & 3.5 & $\begin{array}{l}\text { Worktime } \\
* * *\end{array}$ & & \\
\hline
\end{tabular}

$* \mathrm{~T}_{\text {a.int. }}>\mathrm{T}_{\text {a.ext }}$ and $\mathrm{T}_{\text {a.ext. }}>14^{\circ} \mathrm{C} ; * * \mathrm{~T}_{\text {a.int. }}>\left(\mathrm{T}_{\text {a.ext }}+2\right)$ and $\mathrm{T}_{\text {a.ext. }}>14^{\circ} \mathrm{C} ; * * * \mathrm{~T}_{\text {a.ext. }} \leq 19^{\circ} \mathrm{C}$ and $\mathrm{T}_{\text {a.ext. }}>14^{\circ} \mathrm{C} ; * * * * \mathrm{~T}_{\text {a.ext. }}>19^{\circ} \mathrm{C} ; * * * * \mathrm{~T}_{\text {a.ext. }}>19^{\circ} \mathrm{C}$ and $\mathrm{T}_{\text {a.int. }}>$ $\left(\mathrm{T}_{\mathrm{a} . \mathrm{ext}}+2\right)$. 
Table 3. Fans motor power for the cases studies considered

\begin{tabular}{|c|c|c|c|}
\hline Case study & System type & $\begin{array}{l}\text { Air flow rate } \\
\text { (vol/h) }\end{array}$ & Equipment \\
\hline \multirow[t]{2}{*}{$\mathrm{B}$} & Ventilation & 0.5 & $2 \times 1.1 \mathrm{~kW}$ fan \\
\hline & Ventilation & 3.5 & $2 \times 7.5 \mathrm{~kW}$ fan \\
\hline \multirow[t]{2}{*}{$\mathrm{C}$} & Ventilation & 0.5 & $2 \times 1.1 \mathrm{~kW}$ fan \\
\hline & Ventilation & $3.5+1.5$ & $2 \times 11 \mathrm{~kW}$ fan \\
\hline \multirow[t]{3}{*}{$\mathrm{D}$} & Ventilation & 0.5 & $2 \times 1.1 \mathrm{~kW}$ fan \\
\hline & Ventilation & 3.5 & $2 \times 7.5 \mathrm{~kW}$ fan \\
\hline & DEC & 3.5 & $\begin{array}{l}2 \times 7.5 \mathrm{~kW} \text { fan } \\
(+0.5 \mathrm{~kW} \text { water } \\
\text { pump of DEC) }\end{array}$ \\
\hline \multirow[t]{2}{*}{$\mathrm{E}$} & Ventilation & 0.5 & $2 \times 1.1 \mathrm{~kW}$ fan \\
\hline & IEC & 3.5 & $\begin{array}{l}4 \times 7.5 \mathrm{~kW} \text { fan } \\
(+0.5 \mathrm{~kW} \text { water } \\
\text { pump of DEC) }\end{array}$ \\
\hline \multirow[t]{2}{*}{$\mathrm{F}$} & Ventilation & 0.5 & $2 \times 1.1 \mathrm{~kW}$ fan \\
\hline & IEC & $3.5+1.5$ & $\begin{array}{l}2 \times 11 \mathrm{~kW} \text { fan }(+ \\
0.5 \mathrm{~kW} \text { water } \\
\text { pump of DEC) }\end{array}$ \\
\hline \multirow[t]{2}{*}{ G } & Ventilation & 0.5 & $2 \times 1.1 \mathrm{~kW}$ fan \\
\hline & IEC & $1.5+4.5$ & $\begin{array}{l}2 \times 11 \mathrm{~kW} \text { fan }(+ \\
0.5 \mathrm{~kW} \text { water } \\
\text { pump of DEC) }\end{array}$ \\
\hline \multirow[t]{2}{*}{$\mathrm{H}$} & Ventilation & 0.5 & $2 \times 1.1 \mathrm{~kW}$ fan \\
\hline & IEC & 3.5 & $\begin{array}{l}4 \times 7.5 \mathrm{~kW} \text { fan } \\
(+0.5 \mathrm{~kW} \text { water } \\
\text { pump of DEC) }\end{array}$ \\
\hline
\end{tabular}

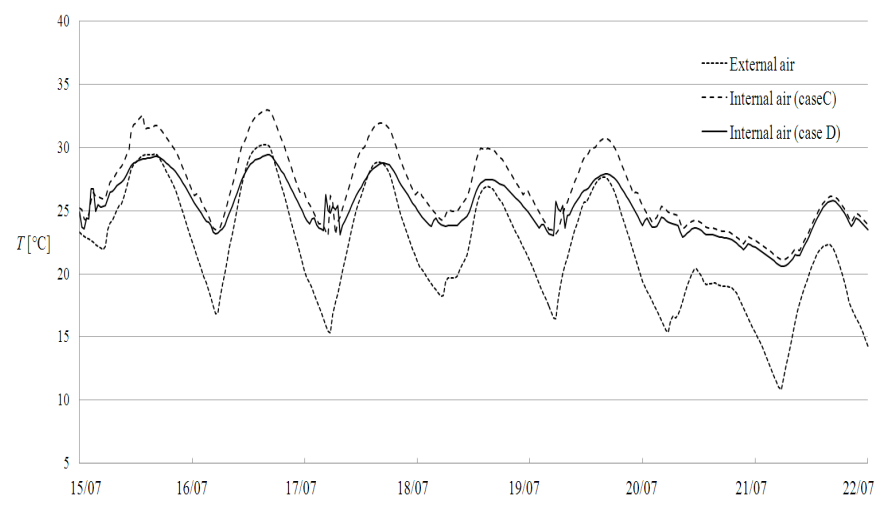

Figure 5. Hourly temperature profiles of internal air with two different ventilation systems (Cases C and D) and external air during the third week of July.

\subsection{Ventilation with cyclic evaporative cooling (case $\mathbf{H}$ )}

In this case the indoor cooling is realised using a multistage configurations to produce greater cooling effects; the indoor cooling is realised using a multi-stage configurations to produce greater cooling effects. The $35 \%$ in volume of the product air, after being cooled within the heat-exchanger by the working air flow, previously subjected to the direct evaporative cooling, returns to DEC apparatus realizing an additional evaporative cooling (Fig.7). This process continued operating for the whole assigned operating time, realizing several cycles, for the assigned operating conditions (Table 2); fans motor power are given in Table 3.
The theoretic limit temperature of the product air in this process was the wet-bulb temperature corresponding the last cycle working air temperature.

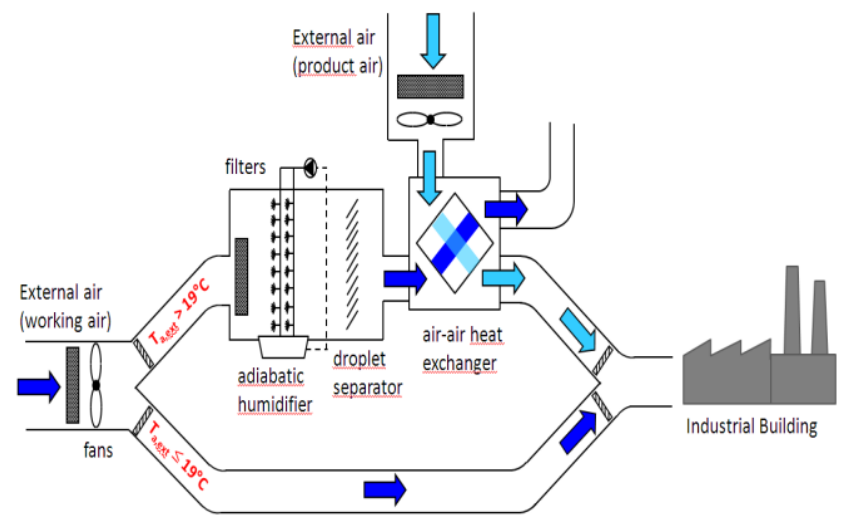

Figure 6(a). Sketch of ventilation plant in case $\mathrm{H}$

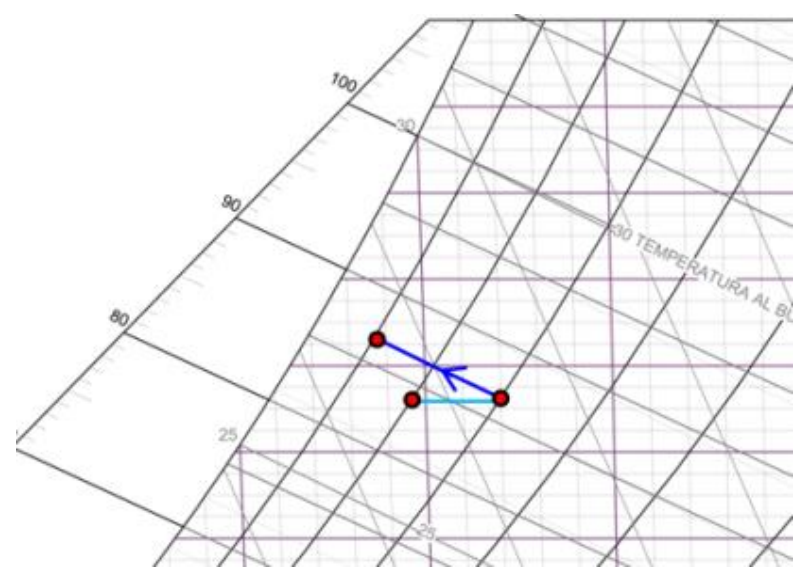

Figure 6(b). Transformation process of external air in case $\mathrm{H}$ on the psychrometric chart

In order to evaluate the overall effect of different systems on internal air temperature, it has been introduced a parameter, the cooling degree days supplied $\left(\mathrm{CDD}_{\mathrm{S}}\right)$, which is a measure of how much (in degrees), and for how long (in days), inside air temperature with a system was lower than a specific base temperature. This parameter reflects the amount of energy needed to cool a building:

$$
\mathrm{CDD}_{\mathrm{S}}=\Sigma_{\mathrm{h}}\left(\mathrm{T}_{\mathrm{int}, \mathrm{j}}-\mathrm{T}_{\mathrm{rif}}\right)_{\mathrm{h}}
$$

Where $T_{\text {int, } j}$ is the internal air temperature produced with system $\mathrm{j}$ and $\mathrm{T}_{\text {rif }}$ is the reference internal air temperature.

Comparisons in terms of cooling degree days (CDDs) between results obtained from simulation of different cases study are reported in Figure 8. As can be noted, cases equipped with an evaporative system show a lower requirement of cooling energy respect to other cases. If the values of energy needed to cool building are so low, can be taken into account a cooling plant.

\section{THERMAL COMFORT}

In this work the Fanger's static model PMV/PPD was used to evaluate the different systems performance in terms of thermal comfort [17]. The Predicted Mean Vote (PMV) 
predicts the individual thermal sensation based on six thermal comfort variables (air temperature, relative humidity, mean radiant temperature, air velocity, clothing thermal resistance, and metabolic rate), parameterised into a heatbalance equation. This indicator has a range from -3 to +3 (where -3 is cold, 0 is neutral, +3 is hot).

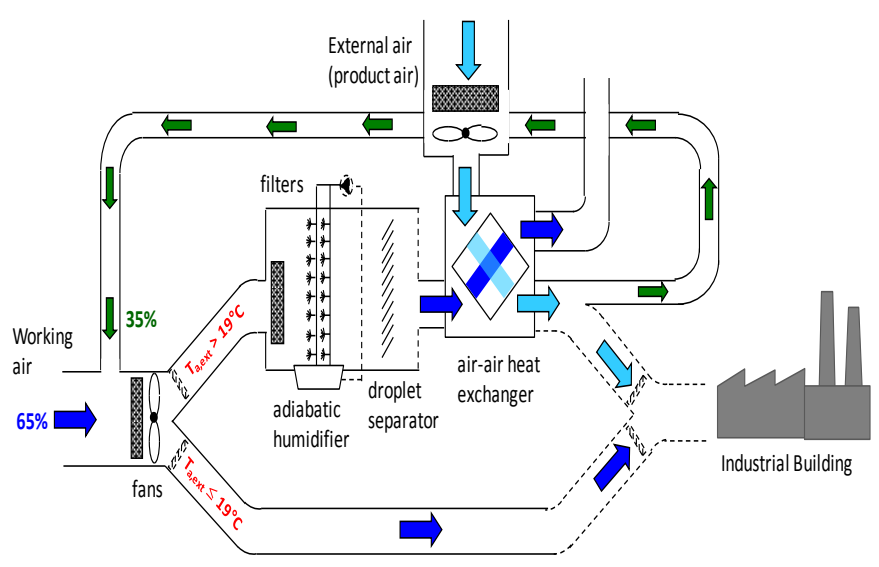

Figure 7(a). Sketch of ventilation plant in case $\mathrm{H}$

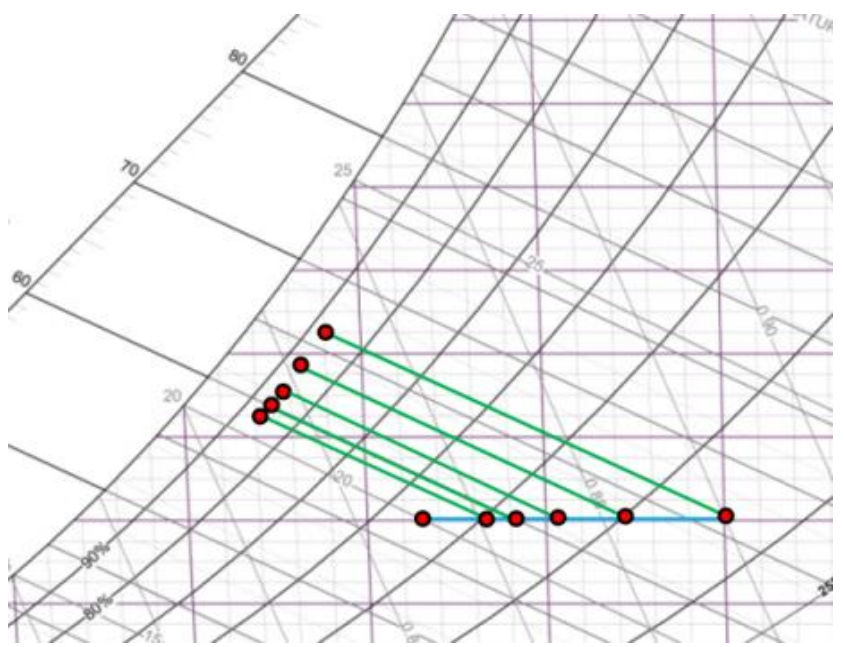

Figure 7(b). Transformation process of external air in case $\mathrm{H}$ on the psychrometric chart

The international standard ISO 7730 presents five methods for predicting the general long term thermal sensation and degree of discomfort of people exposed to moderate thermal environments.

In this paper two different methods, $\mathrm{A}$ and $\mathrm{C}$, as called in Annex H of the ISO Standard, has been used in order to evaluate the conditions for the long-term thermal comfort.

The method A calculates the number or percentage of hours, during which the building is occupied and the PMV is out-of a specified range; it is a very simple and intuitive method, but in this way it does not allow to know how much far from limit is the PMV of a room. Another useful method is that called method C in Annex H. In this method the time during which the PMV exceeds the comfort boundaries is weighted with a factor $\mathrm{w}_{\mathrm{f}}$ which is a function of the PPD. The method $\mathrm{C}$ highlights mainly different quality levels of investigated rooms, however the meaning of the value is less intuitive. This method is based on following elements:

1) The weighting factor $w_{f}$, equals 1 for $P M V=P M V_{l i m}$

Where $\mathrm{PMV}_{\text {lim }}$ is determined by the comfort range calculated according to this International Standard.
2) The weighting factor, $\mathrm{w}_{\mathrm{f}}$, is calculated as:

$$
w_{f}=\frac{P P D_{\text {actualPMV }}}{P P D_{P M V}} \text { for }|\mathrm{PMV}|>\mid \mathrm{PMV} \text { lim } \mid
$$

Where PPD $_{\text {actualPMv }}$ is the PPD value corresponding to the actual PMV and PPDPMVlim is the PPD value corresponding to $\mathrm{PMV}_{\text {limit. }}$

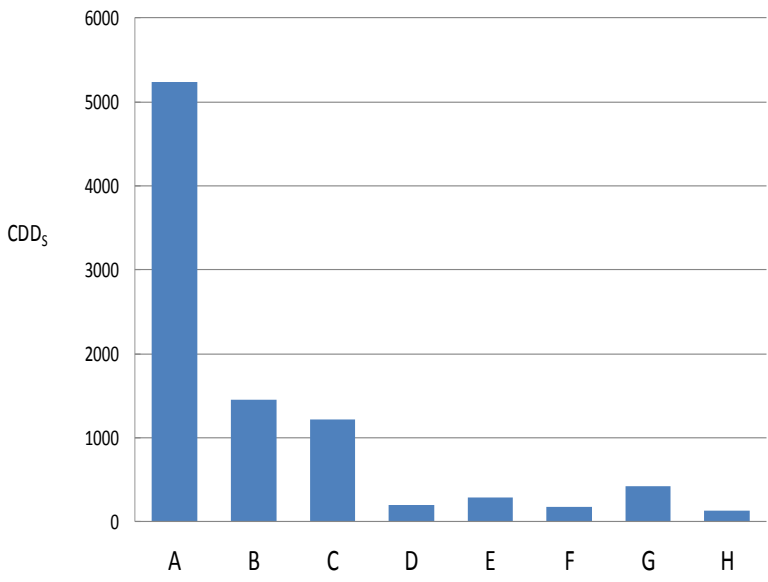

Figure 8. Cooling degree days supplied $\left(\mathrm{CDD}_{\mathrm{S}}\right)$ for all the cases considered evaluated during the period from 15st May to 30th September using a reference internal air temperature equal to $28^{\circ} \mathrm{C}$

3) For a characteristic period during a year, the product of the weighting factor $\mathrm{w}_{\mathrm{f}}$ and the time $\mathrm{t}$, is summed and the result expressed in hours. For the summer period:

$$
\sum w f \cdot t \text { per } \mathrm{PMV}>\mathrm{PMV}_{\text {Limite }}
$$

The International Standard ISO classifies thermal environments in three categories $\mathrm{A}, \mathrm{B}$ and $\mathrm{C}$, reported in Table 4; each category prescribes a maximum percentage dissatisfied (PPD) and relative limits for the PMV.

Table 4. Categories of thermal environment

\begin{tabular}{|c|l|l|}
\hline \multirow{2}{*}{ Category } & \multicolumn{2}{|l|}{ Thermal state of the body as a whole } \\
\cline { 2 - 3 } & PPD (\%) & PMV (\%) \\
\hline A & $<6$ & $-0.2<$ PMV $<+0.2$ \\
\hline B & $<10$ & $-0.5<$ PMV $<+0.5$ \\
\hline C & $<15$ & $-0.7<$ PMV $<+0.7$ \\
\hline
\end{tabular}

This classification affects primarily moderate thermal environments, therefore since the present study concern industrial buildings, it was considered acceptable the third category and it was supposed a further lower additional category corresponding to $-0,9<\mathrm{PMV}<+0,9$.

Note how a value of PMV equal to -1 or +1 corresponds to a thermal sensation respectively of slightly cool or slightly warm, so a value of $P M V$ inside the range $-0,9$ and $+0,9$ can be considered acceptable for a industrial environment. 
The results obtained with method A are shown in Figure 9.

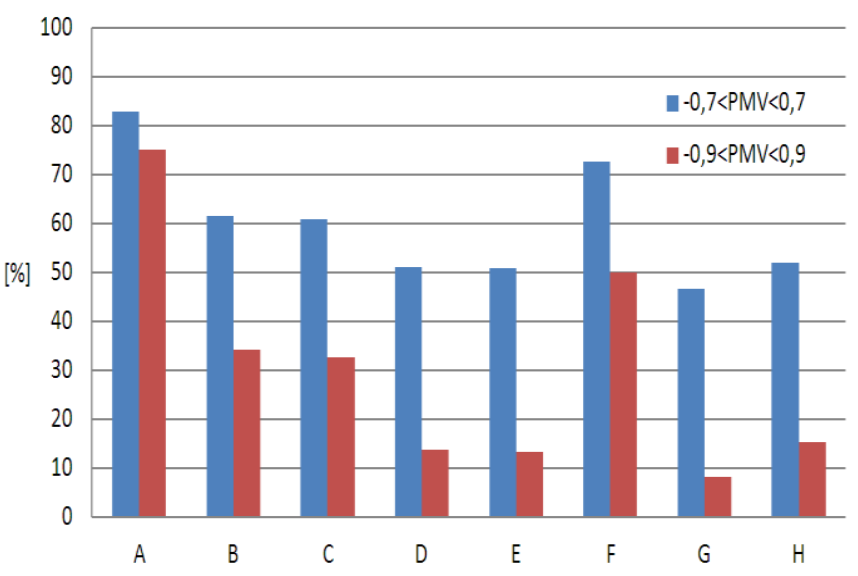

Figure 9. Percentage of hours during which the building is occupied and the PMV is out of the specified range (method

As one can note the cases in which a cooling system is used show a significant reduction of time during which the $P M V$ value is out of the prescribed limits, but in the case $\mathrm{F}$.

Moreover, it appears that a good level of quality in environment can be obtained using a DEC system likewise using an IEC system, which introduces in building air with external moisture content. Therefore, comparing results obtained with DEC system and IEC system, it do not appears in terms of moisture content of internal air, a significant difference with two different systems. Figure 10 reports for cases $D$ and $E$ the aggregate amount of hours during which the relative humidity of the internal air stays below a certain value. It can be observed that the number of hours during which the relative humidity is higher than $60 \%$ is the same for two cases.

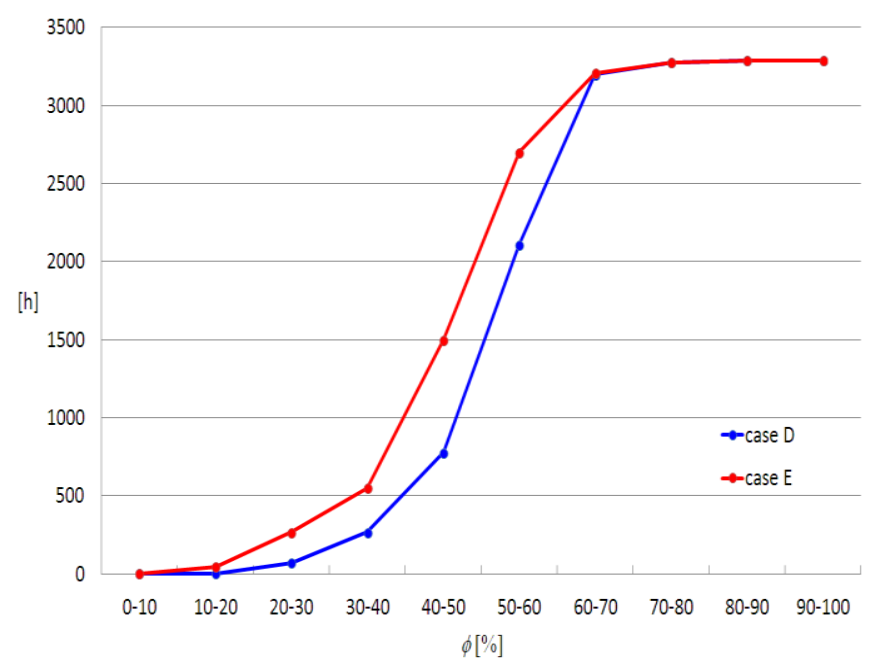

Figure 10. Cumulative distribution for relative humidity of the internal air for cases D and E

The results obtained with method $\mathrm{C}$ are shown in Figure 11. The results obtained with $\mathrm{C}$-method show that the indirect evaporative system corresponding to case $G$ guarantees a thermal comfort level lower respect to other indirect evaporative systems (case $\mathrm{E}$ and case F). On the strength of the comfort level, the better systems are those corresponding to cases $\mathrm{E}$ and $\mathrm{H}$.

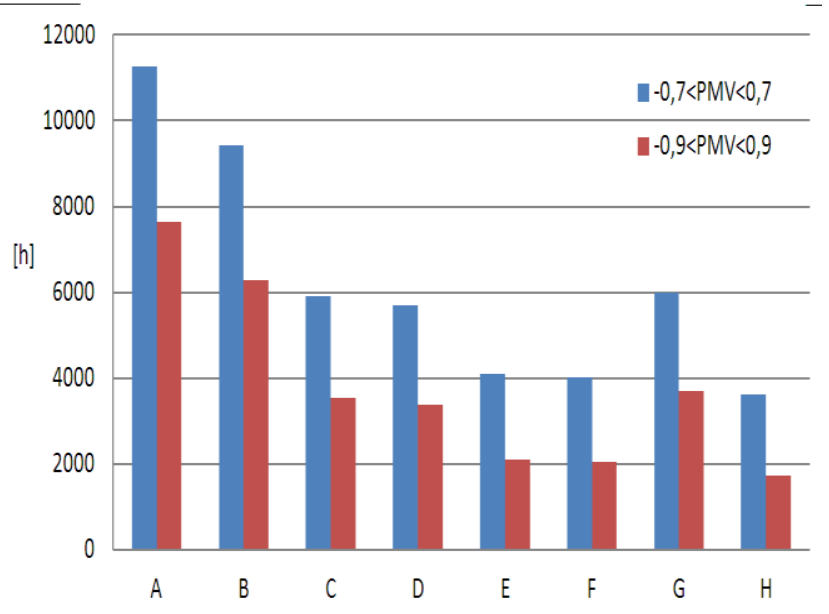

Figure 11. Percentage of hours during which the building is occupied and the PMV is out of the specified range (method C)

\section{RESULTS}

\subsection{Energetic analysis}

Once developed the numerical model in TRNSYS environment and run the simulations, it is possible to discuss the performance of different air cooling systems. According to the settings defined by the operating time and operating conditions given in Table 2 , the simulated period consist of 2378 hours, roughly corresponding to summer period. The operating time represent the sum of the hours during which the motors of the fans are on. Figure 12 reports the electrical energy demand for different cases.

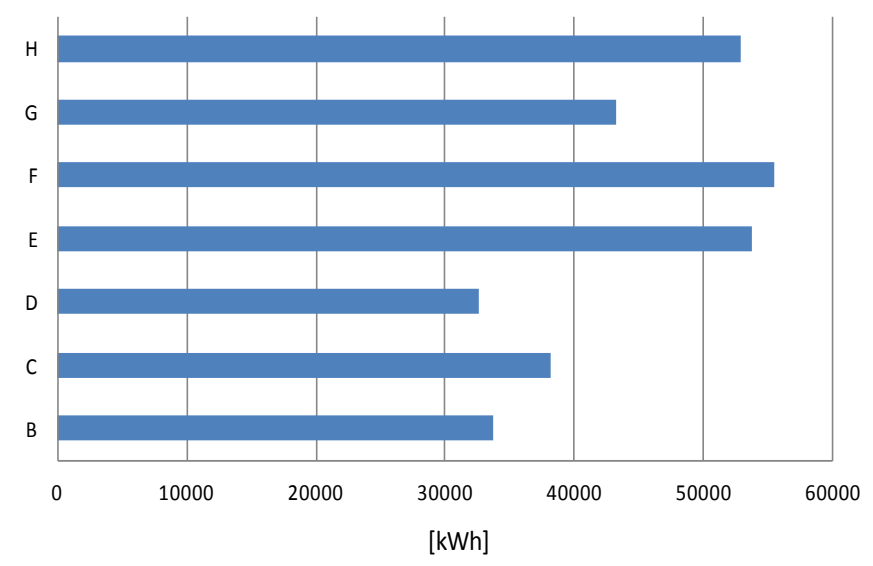

Figure 12. Electrical energy demand for different cases

With reference to the energy consumption, the direct evaporative system (case D) shows the more suitable behavior. The reason is that, in case $\mathrm{D}$, there is an only duct with fans moving air, whereas in indirect evaporative systems (cases E, F, G and $\mathrm{H}$ ) there are two different air flow rates, working air and product air, and so it is needed a greater amount of electrical energy.

Considering both energy saving and thermal comfort performances, a cyclic evaporative system is certainly the better cooling plant solution for industrial buildings, as pointed out in Table 5 where the comparison among the indirect systems is presented. 
It is also evident how the direct evaporative system (case D) performs well, but it is highly sensible to humidity of the external air (Fig. 9). In fact, as shown in Figure 11, when the performances are weighted in terms of distance from the

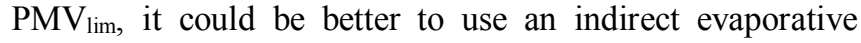
system despite the energy consumption.

In order to compare the behavior of the three IEC systems considered, it is useful introducing a variable, which takes into account both energy saving and thermal comfort. This variable represent the additional energy demand for increase of 1 hour the total time during which the thermal environment stays in category $\mathrm{D}$; it can be expressed as:

$$
E_{\text {th,com }}=\left(E_{\text {IEC }, j}-E\right) /\left(H_{\text {IEC }, j}-H\right)
$$

Where $E_{I E C, j}$ is the electrical energy needed with the $j$-th IEC system, E is the electrical energy needed without any ventilation system, $\mathrm{H}_{\mathrm{IEC}, \mathrm{j}}$ is the amount of satisfaction hours with the $j$-th IEC system, and $\mathrm{H}$ is the amount of satisfaction hours without any ventilation system. $E_{\text {th,com }}$ represent the cost of an additional hour of satisfaction, in terms of electrical energy required; observing values reported in Table 5, it can be noted that systems corresponding to cases $\mathrm{E}, \mathrm{F}$ and $\mathrm{H}$ are preferable respect to system corresponding to case $\mathrm{G}$; in particular case $\mathrm{H}$ is better than all other.

Table 5. Cost of an additional hour of satisfaction comparison among different IEC systems

\begin{tabular}{|l|l|l|l|}
\hline & E (kWh) & H (h) & $\begin{array}{c}\text { Eth,com } \\
(\mathrm{kWh} / \mathrm{h})\end{array}$ \\
\hline E & 20033 & 1117 & 17.9 \\
\hline F & 21802 & 1121 & 19.4 \\
\hline G & 9580 & 350 & 27.4 \\
\hline H & 19167 & 1235 & 15.5 \\
\hline
\end{tabular}

\subsection{Water consumption}

Water consumption is a relevant issue, mainly because of the sample building dimensions and the consequent sizeable wetted-air flow rates. Therefore water consumption has been evaluated as expressed in terms of liters per air cubic meters, for the different evaporative systems analysed. Figure 13 reports the amounts of water required by the different cooling systems.

Among the options considered, the study case $\mathrm{F}$ was characterized by a high water need, and this effect was not mitigated by the operating time, whereas the study case D is characterized by almost the same amount of operating hours but by a smaller amount of water required, as can be note in Table 6, where product air flow rate, evaporated water amount and operating hours for different study cases analyzed are summarized.

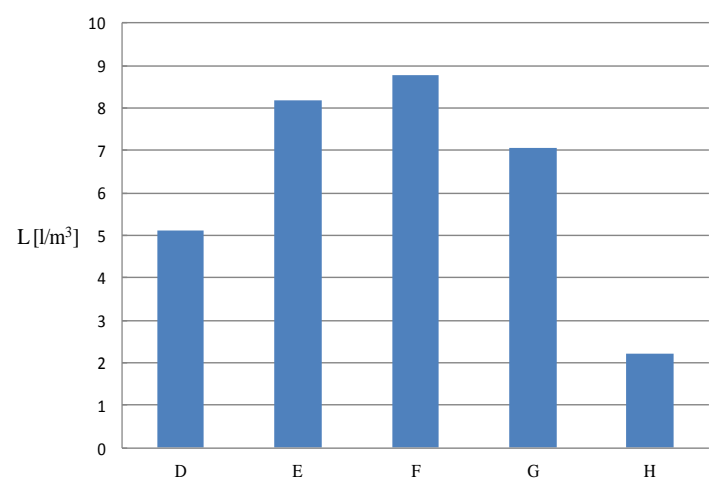

Figure 13. Water consumption per air volume cooled unit during the summer season

Table 6. Average amount of water required during the summer season for the considered cases

\begin{tabular}{|l|l|l|l|l|}
\hline $\begin{array}{l}\text { Case } \\
\text { stud } \\
\mathrm{y}\end{array}$ & $\begin{array}{l}\text { Product- } \\
\text { air flow } \\
\text { rate } \\
\left(\mathrm{m}^{3} / \mathrm{h}\right)\end{array}$ & $\begin{array}{l}\text { Water } \\
\text { evaporate } \\
\text { d rate }(\mathrm{l})\end{array}$ & $\begin{array}{l}\text { Operating } \\
\text { hours in } \\
\text { cooling } \\
\text { mode }(\mathrm{h})\end{array}$ & $\begin{array}{l}\text { Average } \\
\text { amount } \\
\text { of water } \\
\text { required } \\
(\mathrm{l} / \mathrm{h})\end{array}$ \\
\hline $\mathrm{D}$ & 117600 & 171472 & 1335 & 128,5 \\
\hline $\mathrm{E}$ & 117600 & 275088 & 1365 & 201.5 \\
\hline $\mathrm{F}$ & 168000 & 294274 & 1358 & 216.7 \\
\hline $\mathrm{G}$ & 151200 & 236786 & 1011 & 234.2 \\
\hline $\mathrm{H}$ & 117600 & 100822 & 1345 & 74,9 \\
\hline
\end{tabular}

\subsection{Comparison between an evaporative cooler system and a traditional cooling plant}

A further result, obtained by means of this study, arises from a comparison, in terms of electrical consumption, between a plant with fan-coils coupled with a chiller and a plant with evaporative cooler. In order to allow this comparison, it was assumed that the chiller supply the same cooling load as the one supplied from evaporative cooler and, furthermore, that there is an external air ventilation system in addition to the chiller. The free cooling operation run always. The cooling load $\Phi$ supplied from chiller can be expressed as:

$$
\Phi=\dot{m} c_{p}\left(T_{e s t}-T_{i m m}\right) \cdot \Delta \tau
$$

And the electrical load $\mathrm{L}_{\text {elt }}$ required from the chiller can be expressed as:

$$
L_{e l t}=\Phi / C O P
$$

Where the coefficient of performance (COP) of the chiller was supposed equal to 2.5. The cooling and the electrical load are calculated for every time interval when the chiller works.

In addition to the electrical consumption due to the chiller it was taken into account the electrical energy required from motors of fan-coils and from motors of fans used for air external ventilation system. The electrical energy needed for water circulation pump is practically negligible. Figure 14 reports cooling loads and electrical consumptions in case of 
evaporative coolers and fan-coils with chillers; energy consumptions related to the analysed options were significantly low if compared with traditional systems based on vapor compression technology (it is apparent the small amount of electrical energy required from evaporative coolers compare with one required from chillers). The use of an evaporative cooling system allows a significant energy saving. Since the $C O P$ of chillers has been chosen equal to 2.5 , an electrical energy consumption of almost a quarter of supplied cooling load should be expected, instead the electrical consumption calculated (turned out to be almost half) is almost half. This is due to electrical consumption of fans. Nevertheless, the presence of greenhouse gases in refrigerants make this technology even more unattractive.

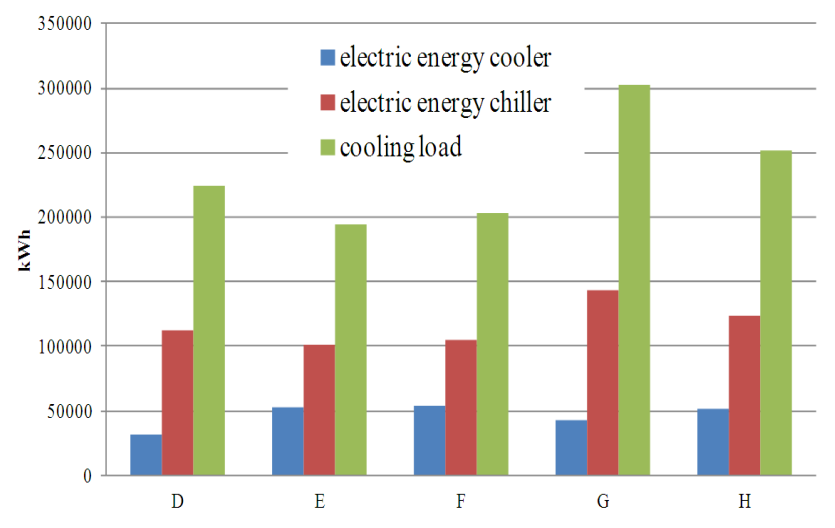

Figure 14. Cooling loads and electrical consumptions for evaporative coolers and fan-coils with chillers

\section{CONCLUSIONS}

The relationship between human productivity and thermal comfort has been validated by several studies, where appear clearly that thermal comfort has a great influence on the productivity and satisfaction of indoor building occupants [18]. There are a large number of factors determining the comfort conditions and these factors are not only measurable parameters but also personal factors. Therefore it is not possible to have thermal-hygrometrical conditions which satisfies all the people inside a building. In particular, the achievement of thermal comfort conditions inside work environments is critical.

A reasonable task for industrial environments is to maintain the percentage of dissatisfied below a certain value or, as pointed out in this study, to reduce the hours of dissatisfaction.

In this work, a sample of an industrial building, located in the North of Italy, was modelled and its thermal behaviour was simulated by TRNSYS. It was considered the summer period, (from $15^{\text {st }}$ May to $30^{\text {th }}$ September) because during this period the effect of internal gains due to machinery is not reduced by thermal losses through the building envelope towards the external environment. With reference to machinery inside the building, different systems have been considered: two ventilation systems with external air, a direct evaporative system, three indirect evaporative systems and a cyclic evaporative cooling system. The different systems are compared in terms of electrical energy consumptions and thermo-hygrometric comfort for the workers. To evaluate the comfort conditions that the different systems guarantee, two methods proposed by international standard ISO 7730 have been used. By means of these methods the percentage of hours during which the occupants are dissatisfied was obtained.

The results show that any evaporative system analysed (direct, indirect or cyclic) allows a significant reduction of dissatisfaction hours with respect to the case which considers a ventilation with external air only. In general, the direct evaporative system proves to be the best choice in terms of thermo-hygrometric comfort level and electrical energy consumptions. However, this system compared to the indirect evaporative system could show some drawbacks due to the moisture content of air they introduce in internal environment, but for the considered location, characterized by a climate not so hot and humid, there is not a significant difference between the two different systems.

Considering both energy saving and thermal comfort performances, a cyclic evaporative system is certainly the better cooling plant solution.

\section{REFERENCES}

1. A. R. Ismail, M. Y. M. Yusof, N. K. Makhtar, B. M. Deros, M. R. A. Rani, Optimization of Temperature Level to Enhance Worker Performance in Automotive Industry, Am. J. Applied Sci., vol. 7, 2010. DOI: 10.3844/ajassp.2010.360.365.

2. A. R. Ismail, N. Jusoh, R. Zulkifli, K. Sopian and B. M. Deros, Thermal Comfort Assessment: A Case Study at Malaysian Automotive Industry, Am. J. Applied Sci., 6 (8), 2009. DOI: 10.3844/ajassp.2009.1495.1501.

3. S. Mohamed and K. Srinavin, Thermal Environment and Construction Worker's Productivity: Some Evidence from Thailand, Building and Environment, vol. 38, 2003. DOI: 10.1016/S0360-1323(02)00067-7.

4. K. Srinavin, S. Mohamed, Forecasting Labor Productivity Changes in Construction Using the PMV Index, International Journal of Ergonomics, vol. 35, 2005. DOI: $10.1016 /$ j.ergon.2004.09.008.

5. J. Zhao, N. Zhu, S. Lu, Productivity Model in Hot and Humid Environment Based on Heat Tolerance Time Analysis, Building and Environment, vol. 44, 2009. DOI: 10.1016/j.buildenv.2009.01.003.

6. Camargo J. R., Ebinuma C. D., Silveira J. L., Experimental Performance of a Direct Evaporative Cooler Operating During Summer in a Brazilian City, Int. J. of Refrigeration, vol.28, 2005. DOI: 10.1016/j.ijrefrig.2004.12.011.

7. Watt J. R., Brown W. K., Evaporative Air Conditioning Handbook, Fairmont Press; 1997.

8. Sodha M. S., Ashutosh S., Kumar A., Sharma A. K., Thermal Performance of an Evaporatively Cooled Multi-Story Building, Building and Environment, vol. 21, 1986. DOI: 10.1016/0360-1323(86)90013-2.

9. Heidarinejad G., Bozorgmehr M., Heat and Mass Transfer Modeling of Two Stage Indirect/Direct Evaporative Air Coolers, ASHRAE, 2008.

10. J. M. Wu, X. Huang, H. Zhang, Theoretical Analysis on Heat and Mass Transfer in a Direct Evaporative Cooler, Applied Thermal Engineering, vol. 29, 2009.

11. H. El-Dessouky, Enhancement of the Thermal Performance of a Wet Cooling Tower, Canadian 
Journal of Chemical Engineering, vol. 74, 1996. DOI: 10.1002/cjce.5450740303.

12. B. Costelloea, D. Finn, Indirect Evaporative Cooling Potential in Air-Water Systems in Temperate Climates, Energy and Buildings, vol. 35, 2003. DOI: 10.1016/S0378-7788(02)00161-5.

13. G. Heidarinejad, M. Bozorgmehr, S. Delfani, J. Esmaeelian, Experimental Investigation of Two-Stage Indirect/Direct Evaporative Cooling System In Various Climatic Conditions, Building and Environment, vol. 44, 2009. DOI: 10.1016/j.buildenv.2009.02.017.

14. G. P. Maheshwari, F. Al-Ragom, R. K. Suri, Energy Saving Potential of an Indirect Evaporative Cooler,
Applied Energy, vol. 69, 2001. DOI: 10.1016/S03062619(00)00066-0.

15. N. J. Stoitchkov, G. I. Dimitrov, Effectiveness of Crossflow Plate Heat Exchanger for Indirect Evaporative Cooling, Int. J. of Refrigeration, vol. 21 (6), 1998. DOI: 10.1016/S0140-7007(98)00004-8.

16. S. K. Wang, Handbook of Air Conditioning and Refrigeration, second edition, McGraw-Hill.

17. Fanger, P. O., Thermal Comfort, Danish Technical Press, Copenaghen, Denmark, 1970.

18. Thermal Comfort in the Workplace: Guidance for Employers, 1999, Health \& Safety Executive (HSE). 